\title{
The VDR gene Fokl polymorphism is associated with gestational diabetes mellitus in Turkish women
}

\author{
Mahmut Apaydın', Selvihan Beysel ${ }^{1,2^{*}}$ D, Nilnur Eyerci ${ }^{3}$, Ferda Alparslan Pinarli ${ }^{3}$, Mustafa Ulubay ${ }^{4}$, \\ Muhammed Kizilgul', Ozhan Ozdemir ${ }^{5}$, Mustafa Caliskan ${ }^{1}$ and Erman Cakal ${ }^{1}$
}

\begin{abstract}
Background: The association between the vitamin D receptor (VDR) gene and gestational diabetes mellitus (GDM) has not been investigated in Turkish pregnant women. We aimed to investigate associations between VDR gene Bsml (rs15444410), Apal (rs7975232), Fokl (rs19735810), and Taql (rs731236) single nucleotide polymorphisms (SNPs) and GDM.

Material-methods: This case-control study comprised 100 women with GDM and 135 pregnant women without GDM. The VDR polymorphism was evaluated using Sanger-based DNA sequencing.

Result: VDR gene Apal, Bsml, and Taql SNPs did not differ between women with and without GDM (each, $p>0.05$ ). Apal, Bsml, and Taql were not associated with GDM risk. The VDR gene Fokl CT/TT genotype was associated with an increased GDM risk (CT vs. CC, OR=1.84, 95\% Cl: [1.05-3.23], $p=0.031$; $\pi$ vs. CC, OR=3.95, 95\% Cl: [1.56-9.96], $p=0.002$; CT/TT vs. CC, OR=2.29, 95\% Cl: [1.35-3.89], $p=0.002$; and CT/CC vs. TT, OR=3.02, 95\% Cl: [1.23-7.38], $p=0.012$ ). The Fokl-TT genotype was more associated with younger age and higher glucose, $\mathrm{HbA1C}$, and $\mathrm{HOMA-IR}$ than the CC and CT genotype. Fokl-T was positively correlated with log-HOMA-IR $(r=0.326, p=0.004)$. Fokl SNPs were independently associated with GDM after adjusting for BMl and age ( $\beta=1.63,95 \% \mathrm{Cl}$ : [1. 2-4.2], $p=0.012$ ). There were no associations between the Fokl, Apal, Bsml and Taql haplotypes and GDM.
\end{abstract}

Conclusion: VDR gene Fokl SNPs were independently associated with having GDM in Turkish women. VDR gene Fokl SNPs might contribute to insulin resistance of developing GDM.

Keywords: VDR gene, Fokl, Gestational diabetes

\section{Background}

Gestational diabetes mellitus (GDM) is defined as glucose intolerance diagnosed during pregnancy [1]. The prevalence of GDM shows differences among ethnic populations and ranges from 1 to $14 \%$ [2]. GDM is characterized by increased insulin resistance, hyperglycemia, and obesity [1, 3-5]. Genetic and environmental factors play an important role in the etiology of GDM [3]. Women with a family history of diabetes mellitus (DM) are at risk of GDM. Women with a history of GDM are at risk of type 2

\footnotetext{
* Correspondence: beyselselvihan@gmail.com

'Department of Endocrinology and Metabolism, Diskapi Yildirim Beyazit Teaching and Research Hospital, Ankara, Turkey

2Department of Medical Biology, Baskent University, Ankara, Turkey Full list of author information is available at the end of the article
}

DM (T2DM) in the future [1-5]. Genetic variations related to $ß$-cell dysfunction and insulin resistance have been shown to contribute to the development of GDM [1, $3,5,6]$. The vitamin D receptor $(V D R)$ gene is actively involved in the insulin metabolic pathway. Vitamin D shows its cellular activity by binding to VDR. Vitamin D plays a role in insulin secretion [7]. Vitamin D deficiency was associated with pre-eclampsia, insulin resistance, and GDM [8]. Active vitamin D shows efficacy by binding to VDR and it has a wide range of genetic variations [9]. The complex of vitamin $\mathrm{D}$ and its receptor is a transcription factor that plays a role in the regulation of insulin secretion from pancreatic beta cells [10]. VDR acts as a ligand-dependent transcription factor and it is a member of the nuclear hormone receptor family. The VDR gene is localized on

(c) The Author(s). 2019 Open Access This article is distributed under the terms of the Creative Commons Attribution 4.0 International License (http://creativecommons.org/licenses/by/4.0/) which permits unrestricted use, distribution, and reproduction in any medium, provided you give appropriate credit to the original author(s) and the source, provide a link to the Creative Commons license, and indicate if changes were made. The Creative Commons Public Domain Dedication waiver (http://creativecommons.org/publicdomain/zero/1.0/) applies to the data made available in this article, unless otherwise stated. 
chromosome 12q13.1, which consists of 11 exons [11-13]. This complex affects immune system regulation [11]. It has an effect on the proliferation, differentiation, and activation of immune cells and cytokine production, and accordingly, DM development [10-12]. Vitamin D deficiency leads to defects in insulin synthesis and secretion $[10,11,13]$.

$V D R$ polymorphisms have been associated with type 1 DM (T1DM) [11] and T2DM [13-15]. BsmI (A $>$ G, rs1544410), ApaI (A >C, rs7975232), TaqI $(\mathrm{T}>\mathrm{C}$, rs731236), and FokI (C> T, rs2228570) are human VDR single-nucleotide polymorphisms (SNPs). VDR gene Bsml, ApaI, and TaqI SNPs are found in 3 prime untranslated regions where gene expression is regulated. FokI leads to $\mathrm{T}>\mathrm{C}$ substitution at exon 2, thus the first translation initiation region is removed, and consequently transcriptional activity of VDR is changed [13, $16]$. Both insulin resistance and impaired insulin secretion play a role in the pathogenesis of GDM and T2DM $[1,3,6]$. The association between $V D R$ gene SNPs and GDM has been investigated in a few studies [12, 16-19]. $V D R$ gene SNPs and GDM have not been investigated in Turkish pregnant women. The present study aimed to investigate associations between VDR gene SNPs (Taq, BsmI, FokI and ApaI) and GDM in Turkish pregnant women.

\section{Methods}

\section{Study population}

Pregnant women who were referred to the Obstetrics and Gynecology Clinic of our tertiary hospital in Ankara from 2014 to 2015 were included in this case-control study. Women with GDM $(n=100)$ and non-diabetic pregnant controls $(n=135)$ were included. The pregnant women were aged 22-38 years and the pregnancy age was 24-28 weeks. Gestational age was assessed from the date of the last menstrual period and clinical assessment. A 2-hour, 75 g oral glucose tolerance test (OGTT) at 24 to 28 weeks' gestation was performed for all pregnant women, irrespective of family history of DM or any other risk factors for GDM. Glucose concentrations after fasting, and 1 and $2 \mathrm{~h}$ after glucose administration $<92 \mathrm{mg} / \mathrm{dL},<180 \mathrm{mg} / \mathrm{dL}$, and $<$ $153 \mathrm{mg} / \mathrm{dL}$, respectively, were considered normal. If a patient's glucose concentration was higher than these values, the patient was diagnosed as having GDM [2]. Women with GDM, who were diagnosed with these criteria, aged 22-38 years, and with pregnancy age 24-48 weeks were included the study. Women with GDM women with chronic disease such as hypertension, thyroid disorders, cardiac, and hepatic or renal dysfunction were excluded. Women without GDM aged 22-38 years and with a pregnancy age of 24-28 weeks who had no diabetes, hypertension, thyroid disorders, cardiac, and hepatic or renal dysfunction were included in the study as controls. Weight, height, and systolic and diastolic blood pressure (BP) were measured in all participants. Serum glucose, insulin, and glycated hemoglobin $\left(\mathrm{HbA}_{1 \mathrm{c}}\right)$ concentrations were measured. Insulin resistance was calculated using the homeostasis model assessment-insulin resistance (HOMA-IR): [fasting plasma insulin ( $\mu \mathrm{IU} /$ $\mathrm{mL}) \mathrm{X}$ fasting plasma glucose $(\mathrm{mg} / \mathrm{dL})] / 405$ [20]. The study was approved by the Diskapi Yildirim Beyazit Teaching and Research Hospital Ethics Board (Number: 26.02.2015-12/21) and written consent was obtained from all participants.

\section{Genotyping}

Genetic analyses for VDR gene SNPs FokI (rs2228570), BsmI (rs1544410), ApaI (rs7975232), and TaqI (rs731236) were performed using Sanger-based DNA sequencing. Genomic DNA was isolated from collected peripheral blood samples of the subjects using a DNA Isolation Kit (Roche Diagnostics, Indianapolis, IN, USA). Genotyping of each HNF1A gene polymorphism was independently performed using a prevalidated fluorescence-based allele-specific polymerase chain reaction (PCR) assay, KASPar (KBiosciences, Hoddesdon, UK), which was performed on a Rotor-Gene Q real-time cycler (Qiagen, Hilden, Germany) according to the manufacturer's instructions. Allele discrimination was made using Rotor-Gene Q software v.2.3.1 (Qiagen, Hilden, Germany). The genotype identification was performed blind without information on clinical phenotypes.

\section{Statistical analysis}

Statistical analysis was performed using SPSS 18.0 (SPSS, Inc) software. Variables are presented as mean \pm standard deviation (SD) or median (min-max), percentages (\%), odds ratios $(O R), 95 \%$ confidence intervals $(\mathrm{CI})$. Normality was tested using the Kolmogorov-Smirnov and Shapiro-Wilk $W$ test. SNPs are expressed as allelic frequency (q) or prevalence of genotypes (\%). Categorical variables were analyzed using the Chi-square test or Fisher's exact test, where appropriate. Student's $t$-test was used for comparisons of normally distributed continuous variables or log-transformed variables between the two groups. The Hardy-Weinberg equilibrium (HWE) at individual loci was assessed using the Chi-square test. Multiple logistic regression analysis and Fisher's exact test were tested using the following models: dominant (major allele homozygotes vs. heterozygotes + minor allele homozygotes), recessive (major allele homozygotes + heterozygotes vs. minor allele homozygotes) and codominant (major allele homozygotes vs. heterozygote and minor allele homozygotes vs. major allele homozygotes). Pair-wise linkage disequilibrium (LD) and correlation coefficients $\left(\mathrm{r}^{2}\right)$ were analyzed using the HAPLOVIEW program. We made a variable reflecting all possible combinations of BsmI-ApaI-TaqI genotypes for each SNP. Statistical significance was defined as a $p<0.05$. 


\section{Results}

Obesity ( 46.2 vs. $18.0 \%, p=0.001)$ and insulin resistance (72.4 vs. $7.2 \%, \mathrm{p}=0.001$ ) were higher in women with GDM than in the non-GDM controls. Serum glucose, insulin, HOMA-IR, HbA1c, BMI, and BPs were higher in the GDM group than in the control group $(p<0.05)$. $25(\mathrm{OH}) \mathrm{D}$ was lower in women with GDM than in the controls $(p<0.05)$. The characteristics of the pregnant women are shown in Table 1. The four SNPs in the control group were within the HWE. Minor allele frequency and the HWE are shown in Table 2.

The distributions of the VDR gene SNPs are shown in Table 3. The frequency of VDR gene ApaI rs7975232, TaqI rs731236 and BsmI rs1544410 did not differ between women with and without GDM in a codominant model and dominant model and recessive model $(p>$ 0.05, each). VDR gene ApaI, TaqI, and BsmI SNPs were not associated with GDM. The frequency of $V D R$ gene FokI rs2228570 differed between women with and without GDM $(p<0.05)$. Compared with the controls, FokI CT genotype (CT vs. CC, OR $=1.84,95 \% \mathrm{CI}$ : [1.05-3.23], $p=0.031$ ) and TT (TT vs. CC, $\mathrm{OR}=3.95,95 \%$ CI: $[1.56-$ 9.96], $p=0.002$ ) genotype were associated with an increased GDM risk in a codominant model, and CT/TT carriers had increased 2.2 odds of having GDM (CT/TT vs. $\mathrm{CC}, \mathrm{OR}=2.29,95 \% \mathrm{CI}$ : [1.35-3.89], $\mathrm{p}=0.002)$ in a dominant model. Compared with the controls, TT genotype carriers had increased 3.02 odds of having GDM (CT/CC vs. TT, $\mathrm{OR}=3.02,95 \% \mathrm{CI}:[1.23-7.38], p=$ 0.012 ) in a recessive model. Gestational age was lower in FokI-TT genotype compared with CC and CT genotype $(p<0.05)$. Glucose, HbA1c, and HOMA-IR were higher

Table 1 Characteristics of subjects

\begin{tabular}{llll}
\hline & Non-GDM $(n=135)$ & GDM $(n=100)$ & $P$ \\
\hline Age (year) & $29.13 \pm 5.20$ & $29.41 \pm 5.02$ & 0.704 \\
Gestational age (weeks) & $26.62 \pm 1.48$ & $26.04 \pm 1.67$ & $\mathbf{0 . 0 1 4}$ \\
Height $(\mathrm{cm})$ & $159.01 \pm 5.90$ & $158.52 \pm 4.95$ & 0.665 \\
Weight $(\mathrm{kg})$ & $68.58 \pm 9.65$ & $75.08 \pm 10.07$ & $\mathbf{0 . 0 0 2}$ \\
BMl $\left(\mathrm{kg} / \mathrm{m}^{2}\right)$ & $26.19 \pm 4.01$ & $29.94 \pm 4.18$ & $\mathbf{0 . 0 0 3}$ \\
Glucose $(\mathrm{mg} / \mathrm{dl})$ & $76.19 \pm 8.93$ & $105.77 \pm 7.81$ & $\mathbf{0 . 0 0 5}$ \\
Insulin $(\mu \mathrm{IU} / \mathrm{ml})$ & $8.01 \pm 1.69$ & $12.83 \pm 4.07$ & $\mathbf{0 . 0 0 2}$ \\
HOMA-IR & $1.52 \pm 0.48$ & $3.36 \pm 1.14$ & $\mathbf{0 . 0 0 3}$ \\
HbA1c $(\%)$ & $4.99 \pm 0.25$ & $5.69 \pm 0.38$ & $\mathbf{0 . 0 0 4}$ \\
25(OH)D & $17.60 \pm 10.24$ & $12.04 \pm 8.51$ & $\mathbf{0 . 0 0 1}$ \\
Systolic BP $(\mathrm{mmHg})$ & $101.37 \pm 11.44$ & $111.77 \pm 14.31$ & $\mathbf{0 . 0 0 8}$ \\
Diastolic BP $(\mathrm{mmHg})$ & $66.01 \pm 7.46$ & $71.08 \pm 7.22$ & $\mathbf{0 . 0 1 2}$
\end{tabular}

$B M I$ body mass index, HOMA-IR homeostasis model assessment-insulin resistance, $H b A 1 c$ hemoglobin $A 1 c, B P$ blood pressure, GDM gestational diabetes mellitus

Student's $t$ test was used for normally distributed continuous variables or logtransformed variables between two groups

Bold represents significant $p$-values in the FokI-TT genotype compared with the CC and CT genotypes $(\mathrm{p}<0.05)$ (Table 4). FokI-T (risk allele) was positively correlated with $\log$-HOMA-IR $(\mathrm{r}=0.326, p=$ 0.004). In the logistic regression analysis, FokI SNPs were independently associated with GDM after adjustig for BMI and age ( $\beta=1.63,95 \% \mathrm{CI}$ : [1. 2-4.2], $p=0.012)$.

\section{Discussion}

This case-control study showed that VDR gene FokI SNPs were independently associated with having GDM in Turkish women. The frequency of the VDR gene FokI TT and CT genotype was increased in women with GDM compared with the non-GDM controls. The frequency of VDR gene ApaI, BsmI, and TaqI SNPs did not differ between women with and without GDM with no association. VDR FokI SNPs might contribute to insulin resistance in the development of GDM.

Our results showed that $25(\mathrm{OH}) \mathrm{D}$ concentrations were lower in the GDM group than in the control group. Vitamin D deficiency was associated with insulin resistance and GDM [8]. The $V D R$ gene has a role in the metabolic pathway of insulin [9]. $V D R$ gene variations have beenshown to be correlated in the development, progression, and complications of T2DM [13-15]. The present study showed that VDR gene FokI SNPs were independently associated with an increased risk of GDM in Turkish women $(\beta=1.63,95 \%$ CI: [1. 2-4.2], $p=$ 0.012). Our study suggested that VDR gene FokI SNPs might be associated with having GDM. We found that the frequency of $V D R$ gene ApaI, TaqI, and BsmI did not differ between women with and without GDM. $V D R$ gene ApaI, TaqI, and BsmI SNPs were not associated with GDM. The VDR gene FokI SNP showed significant differences between women with and without GDM. $V D R$ gene FokI (variant or heterozygotes) compared to wild-type (CC) SNP revealed a significant association. $V D R$ gene FokI rs2228570 TT (TT vs. CC, OR=3.95, 95\% CI: [1.56-9.96], $p=0.002)$ and CT heterozygotes (CT vs. $\mathrm{CC}, \mathrm{OR}=1.84,95 \% \mathrm{CI}$ : $[1.05-3.239, p=0.031$ ) were associated with having GDM, compared with the controls. VDR gene FokI SNPs might contribute to developing GDM in the Turkish population.

Similar to our results, FokI homozygous SNPs were reported as prevalent in patients with DM and GDM [12, 13]. Aslani et al. reported that VDR gene FokI SNPs were associated with GDM in an Iranian population [12]. Another study reported that ApaI and Taq SNPs were associated with GDM in an Iranian population [16]. These results are incompatible with our study, thus we showed that ApaI, Taq, and BsmI SNPs were not associated with GDM. BsmI and FokI SNPs were not associated with GDM in a Saudi Arabian population [17]. Vural and Maltas et al. showed that TaqI SNPs were not associated with T2DM in a Turkish population [15]. 
Table 2 Minor allele frequency and Hardy-Weinberg Equilibrium of VDR gene SNPS

\begin{tabular}{llll}
\hline & Risk allele & MAF for study sample & p for HWE in control \\
\hline Apa I rs7975232 & C & 0.54 & 0.23 \\
Taql rs731236 & C & 0.35 & 0.78 \\
Bsml rs15444410 & G & 0.38 & 0.15 \\
Fokl rs2228570 & T & 0.29 & 0.20 \\
\hline
\end{tabular}

MAF minor allele frequency, HWE Hardy-Weinberg Equilibrium

The Hardy-Weinberg equilibrium (HWE) at individual loci was assessed by Chi-Square test

Dilmec et al. reported that TaqI SNPs were associated with T2DM, but ApaI and FokI SNPs were not associated with T2DM in a Turkish population [14]. Previous studies investigating the VDR gene in Turkish patients with T2DM were compatible with our study. Hence, we supposed that Taq and ApaI were not associated with having T2DM in the Turkish population.
VDR gene Taq, BsmI or ApaI SNPs were not associated with diabetic microvascular complications but only FokI SNPs were associated with diabetic neuropathy in a Caucasian population [13]. Meta-analysis reported that only FokI SNPs were found as a risk factor for T2DM. Taq, BsmI or ApaI SNPs were not associated with DM [21]. These reports were similar to the present study; we

Table 3 Genotype analysis of VDR gene SNPs

\begin{tabular}{|c|c|c|c|c|}
\hline & Non-GDM $(n=134)$ & $\operatorname{GDM}(n=100)$ & OR $(95 \% \mathrm{Cl})$ & $P$ \\
\hline \multicolumn{5}{|l|}{ Apal rs7975232 (\%) } \\
\hline Co-dominant Wild type AA & 19.4 & 17.0 & & \\
\hline Heterozygous AC & 56.7 & 52.0 & $1.04(0.51-2.12)$ & 0.985 \\
\hline Homozygous CC & 23.9 & 31.0 & $1.48(0.67-3.25)$ & 0.326 \\
\hline Dominant $(\mathrm{AA} / \mathrm{AC}+\mathrm{CC})$ & & & $1.17(0.59-2.30)$ & 0.639 \\
\hline Recessive $(\mathrm{AA}+\mathrm{AC} / \mathrm{CC})$ & & & $1.43(0.80-2.56)$ & 0.225 \\
\hline \multicolumn{5}{|l|}{ Taql rs731236 (\%) } \\
\hline Co-dominant Wild type $\Pi$ & 40.0 & 44.0 & & \\
\hline Heterozygous $C T$ & 49.6 & 42.0 & $0.76(0.44-1.33)$ & 0.353 \\
\hline Homozygous CC & 10.4 & 14.0 & $1.22(0.52-2.84)$ & 0.633 \\
\hline Dominant (TT/CT + CC) & & & $0.84(0.50-1.43)$ & 0.539 \\
\hline Recessive $(T T+C T / C C)$ & & & $1.40(0.63-3.10)$ & 0.396 \\
\hline \multicolumn{5}{|l|}{ Bsml rs1544410 (\%) } \\
\hline Co-dominant Wild type AA & 31.9 & 42.0 & & \\
\hline Heterozygous AG & 57.0 & 44.0 & $0.58(0.33-1.02)$ & 0.062 \\
\hline Homozygous GG & 11.1 & 14.0 & $0.95(0.41-2.22)$ & 0.916 \\
\hline Dominant (AA/AG + GG) & & & $0.64(0.37-1.10)$ & 0.109 \\
\hline Recessive (AA+AG/GG) & & & $1.30(0.59-2.83)$ & 0.506 \\
\hline \multicolumn{5}{|l|}{ Fokl rs2228570 (\%) } \\
\hline Co-dominant Wild type CC & 60.0 & 41.0 & & \\
\hline Heterozygous $\subset T$ & 34.1 & 43.0 & $1.84(1.05-3.23)$ & 0.031 \\
\hline Homozygous TT & 5.9 & 16.0 & $3.95(1.56-9.96)$ & 0.002 \\
\hline Dominant $(\mathrm{CC} / \mathrm{CT}+\mathrm{TT})$ & & & $2.29(1.35-3.89)$ & 0.002 \\
\hline Recessive $(C C+C T / T T)$ & & & $3.02(1.23-7.38)$ & 0.012 \\
\hline
\end{tabular}

GDM gestational diabetes mellitus

SNPs were expressed as allelic frequency (q) or prevalence of genotypes (\%)

Categorical variables were analyzed with Chi-square test or Fisher's exact test, where appropriate

Multiple logistic regression analysis and Fisher's exact test were tested using models: dominant (major allele homozygotes vs heterozygotes + minor allele homozygotes), recessive (major allele homozygotes + heterozygotes vs minor allele homozygotes) and codominant (major allele homozygotes vs heterozygote and minor allele homozygotes vs major allele homozygotes)

Bold represents significant $p$-values 
Table 4 Association between the VDR gene Fokl SNPs and clinical features of GDM women

\begin{tabular}{|c|c|c|c|c|c|c|}
\hline & \multirow[t]{2}{*}{ CC (wild) } & \multirow[t]{2}{*}{ CT } & \multirow[t]{2}{*}{$\pi$} & \multirow{2}{*}{$\begin{array}{l}\mathrm{P}^{\mathrm{a}} \\
\mathrm{CC} / \mathrm{CT}\end{array}$} & \multirow{2}{*}{$\begin{array}{l}\mathrm{P}^{\mathrm{b}} \\
\mathrm{CC} / \mathrm{TT}\end{array}$} & \multirow{2}{*}{$\begin{array}{l}\mathrm{P}^{\mathrm{C}} \\
\mathrm{CT} / \mathrm{TT}\end{array}$} \\
\hline & & & & & & \\
\hline Age (year) & $30.04 \pm 5.24$ & $29.46 \pm 5.31$ & $29.14 \pm 3.79$ & 0.515 & 0.315 & 0.588 \\
\hline Gestational age (weeks) & $26.60 \pm 1.66$ & $26.43 \pm 1.50$ & $25.42 \pm 1.39$ & 0.893 & 0.031 & 0.033 \\
\hline BMI $\left(\mathrm{kg} / \mathrm{m}^{2}\right)$ & $27.95 \pm 4.11$ & $29.16 \pm 4.63$ & $28.61 \pm 3.56$ & 0.311 & 0.264 & 0.690 \\
\hline Glucose (mg/dl) & $87.06 \pm 17.04$ & $91.80 \pm 16.66$ & $99.42 \pm 14.53$ & 0.152 & 0.002 & 0.020 \\
\hline İnsulin ( $\mu \mathrm{lU} / \mathrm{ml})$ & $10.19 \pm 4.01$ & $9.88 \pm 3.71$ & $12.17 \pm 3.60$ & 0.380 & 0.036 & 0.009 \\
\hline HOMA-IR & $2.30 \pm 1.31$ & $2.33 \pm 1.16$ & $3.05 \pm 1.20$ & 0.888 & 0.009 & 0.013 \\
\hline $\mathrm{HbA1c}(\%)$ & $5.29 \pm 0.50$ & $5.33 \pm 0.47$ & $5.47 \pm 0.33$ & 0.738 & 0.011 & 0.019 \\
\hline
\end{tabular}

${ }^{a}$ CC genotype vs CT genotype ${ }^{b}$ CC genotype vs TT genotype

${ }^{\mathrm{C}} \mathrm{CT}$ genotype vs $\Pi \mathrm{T}$ genotype

$B M I$ body mass index, HOMA-IR homeostasis model assessment-insulin resistance, $H b A 1 c$ hemoglobin A1c

Student's $t$ test was used for normally distributed continuous variables or log-transformed variables between two groups

Bold represents significant $p$-values

showed that only FokI SNPs were associated with having GDM. A meta-analysis showed that only BsmI SNPs were associated with autoimmune T1DM in an Asian population [11]. We supposed that autoimmunity might contribute to the association between BsmI SNPS and having T1DM. The inconsistency between studies might result from ethnic diversity and environmental factors on $V D R$ variations in different populations [12].

The present study showed that the FokI-T (risk allele) was positively correlated with log-HOMA-IR. Assessment of allele frequency distribution showed a significant association of the FokI variant allele $(\mathrm{T})$ on susceptibility toward to GDM. We supposed that the FokI variant might contribute to impaired insulin resistance and metabolic disorder in developing GDM. Hence, FokI SNPs might have a role in the pathogenesis of GDM.

BsmI, ApaI, and TaqI polymorphisms of the VDR gene are found in the three-primer untranslated region ( $3^{\prime}$-UTR) and have been shown to be in strong linkage disequilibrium (LD) [21]. The FokI polymorphism was reported as an independent marker of the VDR gene because it has not been shown to be in linkage disequilibrium with any of other $V D R$ polymorphisms [12]. Our study reported that VDR gene FokI, ApaI, BsmI and TaqI haplotypes were not associated with GDM, and ApaI, BsmI and TaqI polymorphisms were not shown in LD. $A p a I$ and BsmI polymorphisms of the VDR gene, both in intron 8 , are considered as silent SNPs. These polymorphisms do not change the amino acid sequence of the encoded protein, but they might affect gene expression by modulating stability of mRNA [21]. The TaqI polymorphism is located at codon 352 in exon 9 of the VDR gene. The TaqI TT genotype (absence of restriction site) is related to lower active vitamin D3 [21]. The only locus with impact on the structure of VDR protein is the FokI polymorphism, which is located on the $5^{\prime}$ end region of the VDR gene. The VDR gene FokI polymorphism is functional because it is found in a coding sequence. The
FokI polymorphism is located in the first ATG starting code of VDR protein. FokI is involved in thymine to cytosine $(\mathrm{T} / \mathrm{C})$ substitution at exon 2, the first translation initiation region is removed, and transcriptional activity of VDR is changed [12, 13, 16, 22]. It alters the ACG codon, which is found ten base pairs upstream from the translation starting codon and leads to the generation of an additional starting codon. Two different VDR isoforms occur with transition of allele $\mathrm{T}$ to $\mathrm{C}$ in ATG. When initiating translation starts from this alternative site in the thymine variant, it generates a longer VDR protein comprised of 427 amino acids. The gene is transcribed in normal length if there is a restriction site. Thus, the $\mathrm{C} / \mathrm{C}$ allele codes a 424-amino acid protein and the $\mathrm{T} / \mathrm{T}$ allele codes a $42 \mathrm{7}$-amino acid protein. The longer VDR protein has low activity in transcription, accordingly activation is decreased in target cells $[12,13]$. The FokI T/T genotype, FokI $\mathrm{C} / \mathrm{C}$, showed 1.7-fold greater function in vitamin $\mathrm{D}$-dependent transcriptional activation of a reporter through the regulation of a vitamin D response element [22]. The FokI rs2228570 polymorphism is the only $V D R$ gene polymorphism involved in the generation of altered protein expression [12]. Apart from obesity and insulin resistance, complex genetic (ethnicity) and non-genetic (epigenetic) mechanisms may have a role in the etiology of GDM [9].

The cross-sectional design, small sample size, and absence of postpartum follow-up are the limitations of this study.

\section{Conclusion}

This study showed that VDR gene FokI SNPs were independently associated with an increased risk of GDM in Turkish pregnant women. VDR gene FokI SNPs may be considered as a risk factor for metabolic disorders in GDM. VDR FokI SNPs may have a role in the etiology of GDM. Further studies in different populations are needed to confirm these results. 


\section{Abbreviations}

25(OH) vitamin $\mathrm{D}_{3}$ : 25 -hydroxyvitamin $\mathrm{D}_{3}$; $\mathrm{BMl}$ : body mass index; $\mathrm{BP}$ : blood pressure; GDM: gestational diabetes mellitus; HbA1c: hemoglobin A1c; HOMA-IR: homeostasis model assessment-insulin resistance index; LD: Pairwise linkage disequilibrium

\section{Acknowledgements}

Not applicable.

\section{Funding}

No funding sources for research.

\section{Availability of data and materials}

The datasets used and/or analysed during the current study available from the corresponding author on reasonable request.

\section{Authors' contributions}

MA and SB, contributions to conception and design, or acquisition of data, or analysis and interpretation of data, involved in drafting the manuscript and approved the final manuscript, FAP, NE, MU, MK, OO and MC contributions to conception and design, or acquisition of data, or analysis and interpretation of data and approved the final manuscript; EC, revising it critically for important intellectual content; and have given final approval of the version to be published.

\section{Ethics approval and consent to participate}

This retrospective study was approved by Diskapi Yildirim Beyazit Teaching and Research Hospital Ethics Board (Number.26.02.2015-12/21) and written consent was obtained from the patients.

\section{Consent for publication}

Not applicable.

\section{Competing interests}

The authors declare that they have no competing interests.

\section{Publisher's Note}

Springer Nature remains neutral with regard to jurisdictional claims in published maps and institutional affiliations.

\section{Author details}

'Department of Endocrinology and Metabolism, Diskapi Yildirim Beyazit Teaching and Research Hospital, Ankara, Turkey. ${ }^{2}$ Department of Medical Biology, Baskent University, Ankara, Turkey. ${ }^{3}$ Department of Genetic Research, Diskapi Yildirim Beyazit Teaching and Research Hospital, Ankara, Turkey. ${ }^{4}$ Department of Obstetrics and Gynecology, Gulhane School of Medicine, Ankara, Turkey. ${ }^{5}$ Department of Obstetrics and Gynecology, Ankara Numune Teaching and Research Hospital, Ankara, Turkey.

Received: 26 September 2018 Accepted: 7 May 2019

Published online: 16 May 2019

\section{References}

1. Zhang C, Bao W, Rong Y, Yang H, Bowers K, Yeung E, Kiely M. Genetic variants and the risk of gestational diabetes mellitus: a systematic review. Hum Reprod Update. 2013;19:376-90.

2. International Association of Diabetes \& Pregnancy Study Groups (IADPSG) Consensus Panel Writing Group and the Hyperglycemia \& Adverse Pregnancy Outcome (HAPO) Study Steering Committee, Metzger BE, Gabbe SG, Persson B, Buchanan TA, Catalano PM, Damm P, Dyer AR, Hod M, Kitzmiller $\mathrm{JL}$, et al. The diagnosis of gestational diabetes mellitus: new paradigms or status quo? J Matern-Fetal Neonatal Med Off J Eur Assoc Perinat Med Fed Asia Ocean Perinat Soc Int Soc Perinat Obstet. 2012;25:2564-9.

3. Mao H, Li Q, Gao S. Meta-analysis of the relationship between common type 2 diabetes risk gene variants with gestational diabetes mellitus. PLoS One. 2012;7:e45882.

4. Huopio H, Cederberg H, Vangipurapu J, Hakkarainen H, Pääkkönen M Kuulasmaa T, Heinonen S, Laakso M. Association of risk variants for type 2 diabetes and hyperglycemia with gestational diabetes. Eur J Endocrinol Eur Fed Endocr Soc. 2013;169:291-7.
5. Lauenborg J, Grarup N, Damm P, Borch-Johnsen K, Jørgensen T, Pedersen $\mathrm{O}$, Hansen T. Common type 2 diabetes risk gene variants associate with gestational diabetes. J Clin Endocrinol Metab. 2009;94:145-50.

6. Kwak SH, Kim S-H, Cho YM, Go MJ, Cho YS, Choi SH, Moon MK, Jung HS, Shin HD, Kang HM, et al. A genome-wide association study of gestational diabetes mellitus in Korean women. Diabetes. 2012;61:531-41.

7. Sintov AC, Yarmolinsky L, Dahan A, Ben-Shabat S. Pharmacological effects of vitamin D and its analogs: recent developments. Drug Discov Today. 2014;19:1769-74.

8. Aghajafari F, Nagulesapillai T, Ronksley PE, Tough SC, O'Beirne M, Rabi DM. Association between maternal serum 25-hydroxyvitamin D level and pregnancy and neonatal outcomes: systematic review and meta-analysis of observational studies. BMJ. 2013;346:f1169.

9. Tuoresmäki P, Väisänen S, Neme A, Heikkinen S, Carlberg C. Patterns of genome-wide VDR locations. PLoS One. 2014;9:e96105.

10. Bid HK, Konwar R, Aggarwal CG, Gautam S, Saxena M, Nayak VL, Banerjee M. Vitamin D receptor (Fokl, Bsml and Taql) gene polymorphisms and type 2 diabetes mellitus: a north Indian study. Indian J Med Sci. 2009;63:187-94.

11. Zhang J, Li W, Liu J, Wu W, Ouyang H, Zhang Q, Wang Y, Liu L, Yang R, Liu X, et al. Polymorphisms in the vitamin $\mathrm{D}$ receptor gene and type 1 diabetes mellitus risk: an update by meta-analysis. Mol Cell Endocrinol. 2012;355:135-42.

12. Aslani S, Hossein-Nezhad A, Mirzaei K, Maghbooli Z, Afshar AN, Karimi F. VDR Fokl polymorphism and its potential role in the pathogenesis of gestational diabetes mellitus and its complications. Gynecol Endocrinol Off 」 Int Soc Gynecol Endocrinol. 2011;27:1055-60.

13. Liu, Z., Liu, L., Chen, X., He, W., and Yu, X. (2014). Associations study of vitamin $\mathrm{D}$ receptor gene polymorphisms with diabetic microvascular complications: a meta-analysis. Gene 2014, 546 (1), 6-10.

14. Dilmec F, Uzer E, Akkafa F, Kose E, van Kuilenburg ABP. Detection of VDR gene Apal and Taql polymorphisms in patients with type 2 diabetes mellitus using PCR-RFLP method in a Turkish population. J Diabetes Complicat. 2010;24:186-91.

15. Vural HC, Maltas E. RT-qPCR assay on the vitamin D receptor gene in type 2 diabetes and hypertension patients in Turkey. Genet Mol Res GMR. 2012;11:582-90.

16. Rahmannezhad G, Mashayekhi FJ, Goodarzi MT, Rezvanfar MR, Sadeghi A. Association between vitamin $\mathrm{D}$ receptor Apal and Taql gene polymorphisms and gestational diabetes mellitus in an Iranian pregnant women population. Gene. 2016;581:43-7.

17. El-Beshbishy HA, Tawfeek MA, Taha IM, FadulElahi T, Shaheen AY, Bardi FA, Sultan II. Association of vitamin D receptor gene Bsml (a>G) and Fokl (C>T) polymorphism in gestational diabetes among Saudi women. Pak J Med Sci. 2015:31:1328-33.

18. Tawfeek M. Vitamin D receptor Bsml gene polymorphisms and gestational diabetes mellitus: a Saudi study. Br J Med Med Res. 2011;1:459-68.

19. Wang Y, Wang O, Li W, Ma L, Ping F, Chen L, Nie M. Variants in vitamin D binding protein gene are associated with gestational diabetes mellitus. Medicine (Baltimore). 2015;94:e1693.

20. Mather KJ, Hunt AE, Steinberg HO, Paradisi G, Hook G, Katz A, Quon MJ, Baron AD. Repeatability characteristics of simple indices of insulin resistance: implications for research applications. J Clin Endocrinol Metab. 2001:86:5457-64.

21. Li L, Wu B, Liu J-Y, Yang L-B. Vitamin D receptor gene polymorphisms and type 2 diabetes: a meta-analysis. Arch Med Res. 2013;44:235-41.

22. Gross C, Krishnan AV, Malloy PJ, Eccleshall TR, Zhao XY, Feldman D. The vitamin $D$ receptor gene start codon polymorphism: a functional analysis of Fokl variants. J Bone Miner Res Off J Am Soc Bone Miner Res. 1998;13:1691-9.

\section{Ready to submit your research? Choose BMC and benefit from:}

- fast, convenient online submission

- thorough peer review by experienced researchers in your field

- rapid publication on acceptance

- support for research data, including large and complex data types

- gold Open Access which fosters wider collaboration and increased citations

- maximum visibility for your research: over $100 \mathrm{M}$ website views per year

At BMC, research is always in progress.

Learn more biomedcentral.com/submissions 